https://dx.doi.org/10.4314/ijs.v19i2.10

Ife Journal of Science vol. 19, no. 2 (2017)

\title{
EFFICACY OF INTERVENTION STRATEGIES FOR BIOREMEDIATION OF CRUDE OIL IN POLLUTED SOIL MICROCOSM
}

\author{
*Buraimoh, O.M ${ }^{1}$, Ogunyemi, A.K ${ }^{1}$ Ibrahim, N.H ${ }^{1}$, Adebusoye, A.S ${ }^{1}$, Ilori, M.O ${ }^{1}$ and \\ Amund, $\mathbf{O . O}^{1}$. \\ ${ }^{1}$ Department of Microbiology, University Of Lagos, Akoka, Lagos, Nigeria. \\ *Correspondence Author's Email Address: oburaimoh@unilag.edu.ng; marianiks@yahoo.com \\ (Received: $26^{\text {th }}$ October, 2016; Accepted: $13^{\text {th }}$ August, 2017)
}

\section{ABSTRACT}

\begin{abstract}
Crude oil, though not manmade but largely manipulated by man to provide different oil-based products has become a major source of environmental pollution. This menace on land do contribute to the retardation of vegetation growth and human health hazards, while in water it may be toxic to aquatic animals. The search for the solution to ameliorate the seemingly unending pollution and its side effects necessitated the evaluation on the effect of bioaugmentation, biostimulation and natural attenuation of crude oil pollution in soil microcosms. The bacterial species selected for this study (Bacillus thuringensis strain LG32 and Burkolderia psendomallei strain A81) were preliminarily identified using the conventional biochemical tests and further identification was carried out using the API kit. The results of the study carried out over a period of five weeks indicated that there was a marked reduction in the available phosphorous and potassium in the bioaugmented and biostimulated soils compared with that of the control. The mean values for total viable counts (TVC) of population of hydrocarbon utilizing bacteria (HUB) was higher in the bioaugmented soil ranged (LG32=6.0-7.5log10 $\mathrm{cfu} \mathrm{g}^{-1} ; \mathrm{A} 81=5.5$ -

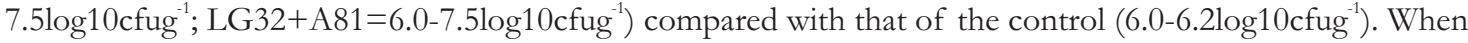
bioaugmentation was combined with biostimulation, the soil had higher counts of HUB (6.0-9.0log10 $\left.\mathrm{cfug}^{-1}\right)$ and HUF (3.5-6.5log10 $\mathrm{cug}^{-1}$ ) compared to bioaugmentation without stimulation (HUB: 6.0-7.5; HUF: 3.5-5.5). The GC result indicated that by day $35,96.92 \%$ of the aliphatic and aromatic components have been degraded in the augmented soil, higher than the natural attenuation control.
\end{abstract}

Key words: Biodegradation, Biostimulation, Bioaugmentation, Microcosm, Attenuation, Metabolize.

\section{INTRODUCTION}

Petroleum in its natural state is called crude oil (Ukoli, 2003). Crude oil ranges from fluid volatile liquids to viscous, semi-solid materials (Ojo and Adebusuyi, 1996; Onifade et al., 2007; Speight, 2014). The components of crude oil can be divided into four major groups which include the saturates, aromatics, resins and asphlatenes (Leahy and ColweIl, 1990; Chandra and Norhusna, 2012; Cho et al., 2012). Generally, saturated alkanes are known to be the most degradable fraction in crude oil (Atlas, 1981; Jones et al, 2007; Mohammed et al., 2013) while those of $C_{10}$ to $C_{20}$ are said to be among the first to be degraded by microorganisms (Atlas, 1995; Amouric et al., 2006; Koukkou and Vandera, 2011).

Though not manmade, crude oil are manipulated by man to provide various consumable products and has become a major source of environmental pollution (Aboribo, 2001). The extensive pollution of the environments constitute socio-economic and public hazards (Kobayashi and Rittman, 1982;
Akubugwo et al., 2009). A large and mostly hazardous subgroup of petroleum compounds is the Poly-Aromatic Hydrocarbons (PAHs) (Irwin et al., 1997). The soluble compounds of diesel include benzene, toluene, ethyl benzene and xylene, known as BTEX are also toxic to aquatic life, animals and humans; affecting liver, kidneys, lungs and nervous system leading to cancer, immunlogical, reproductive, ferotoxic and genotoxic effects (Davies et al., 1993; Irwin et al., 1977; Rushton et al., 2007). Another major effect of oil pollution is the prevention of normal oxygen exchange between soil and atmosphere due to hydrophobic properties (Atlas, 1977; Onuoha et al., 2003; Adedokun and Ataga, 2007; Onuh et al., 2008). It also inhibits seed germination and retard plant growth for a long period of time until natural process is re-established (Odjegha and Sadiq, 2002; Nano et al., 2003). Crude oil spills in water may be toxic to aquatic animals (Leahy and CoIwell, 1990; Anon, 2003). Compared with other remediation technologies, biodegradation by indigenous populations of microorganisms is a 
cost effective method of removing hydrocarbon pollutants from the environment (Leahy and Colwell, 1990). Even though they are widely distributed in nature, it may be difficult to obtain hydrocarbon degrading microorganisms with degradative abilities for all the components of petroleum. Complete degradation of oil constituents is mostly achieved from the activities of a consortium consisting of a mixture of microorganisms with degradative abilities for the various components of petroleum. This is because individual organisms are able to metabolize a limited range of hydrocarbon substrates (Ko and Lebeault, 1999; Obayori et al., 2009). Bacteria, yeasts, actinomycetes and filamentous fungi are capable of breaking down hydrocarbons but bacteria have been applauded as the most important in the biodegradative process. According to Atlas (1992), the more frequently isolated bacteria from hydrocarbon-polluted sites belong to the genera Pseudomonas, Rhodococcus, Bacillus, Sphingomonas, Acinetobacter, Alcaligenes, Micrococcus, Flavobacterium, Arthrobacter, Mycobacterium, Actinobacter and Alcanivorax.

Bacteria and fungi are known to metabolize complex molecules depending on their abilities to produce specific enzymes. The concentration of the contaminants, its biodegradability, the properties of the contaminated soil, the selected treatment technology, natural indigenous microbial population, longevity; toxicity and bioavailability of the contaminants, and water mobility in soil may influence the degree of bioremediation. In addition, the bioavailability of contaminants varies with the type of hydrocarbon and soil characteristics, therefore, the physical, chemical and biological soil characteristics will also constitute a determining factor in the choice of remediation techniques to be employed (Cunningham and Philip, 2000). Bioremediation is a widely accepted, cost-effective clean up technology for the rehabilitation of hydrocarboncontaminated soils and will go a long way to alleviate the socio-economic problems. This microcosm study evaluated the efficacy of bioaugmentation, biostimulation and natural attenuation on soils polluted with crude oil. It also isolated, characterized and identified the hydrocarbon utilizing bacteria and fungi in the polluted soil.

\section{MATERIALS AND METHODS Chemicals, Reagents and Suppliers}

Crude oil (Bonny light) was sourced from Chevron, Nigeria. Unless otherwise stated, all other chemicals and disposable materials were obtained from Bristol Scientific Limited, Apapa, Lagos, Nigeria.

\section{Sampling and experimental design}

Six aluminum trays, each filled with $2.0 \mathrm{~kg}$ of agricultural soil were collected from the botanical garden of the University of Lagos, Akoka, Nigeria. The trays were placed in the oven $\left(70^{\circ} \mathrm{C}\right)$ for $24 \mathrm{~h}$ to attain stable moisture. Bonny light crude oil $(200 \mathrm{ml})$ was poured into each of the trays containing the soil samples. The trays were labeled A,B,C,D,E and F. Tray A, was the control (used as a microcosm for natural attenuation). Other set ups (B,C,D, E and F) contained isolates LG32, A81, mixed culture of isolates (LG32 + A81), isolates + nutrients and nutrients only respectively. Samples $(20.0 \mathrm{~g})$ were collected at regular intervals of 7 days from each of the trays for physicochemical, microbial and gas chromatographic analyses.

\section{Media}

Minimal salts medium was used for the enrichment culture as previously described by Kastner et al. (1994). The medium contained the following constituents in $\mathrm{g} / \mathrm{L}$ distilled water: $\mathrm{Na}_{2} \mathrm{HPO}_{4}-2.13, \mathrm{KH}_{2} \mathrm{PO}_{4}-1.30, \mathrm{NH}_{4} \mathrm{CI}-0.50$, $\mathrm{MgSO}_{4} \cdot 7 \mathrm{H}_{2} 0-0.20$, yeast extract- 0.055 and trace elements- $1.0 \mathrm{ml}$. The $\mathrm{pH}$ of the medium was adjusted to 7.2 before autoclaving. Other media used in the course of this project include Luria Bertani, Nutrient agar; potato dextrose agar and blood agar (Oxoid) were prepared according to the manufacturers' instructions.

\section{Determination of total microbial population (Bacteria and Fungi)}

The soil $(1.0 \mathrm{~g})$ was weighed into $9.0 \mathrm{ml}$ of sterile distilled water; serial dilutions of the soil suspension were made. Aliquots $(0.1 \mathrm{ml})$ were then taken from $10^{-5}$ and $10^{-6}$ dilutions and plated in duplicate on to nutrient agar plates for bacteria while same quantity was plated in duplicate on potato dextrose agar for fungi. These were incubated at room temperature for $24 \mathrm{~h}$ for bacteria and $72 \mathrm{~h}$ for fungi. Colonies on the plates 
were afterward enumerated. Total hydrocarbon - degrading bacteria and
fungi

Serial dilutions of the soil samples were made, aliquots $(0.1 \mathrm{ml})$ from $10^{-5}$ and $10^{-6}$ dilutions, were plated on sterile minimal agar plates. Crude oil (sole carbon source) was introduced by vapour phase transfer by placing sterile filter paper discs impregnated with the oil into the lids of Petridishes as described by Raymond et al. (1976). A paper tape was used to seal the Petri-dishes and the lids to prevent the oil vapour from escaping. The $\mathrm{pH}$ of the minimal salts agar used for fungi was adjusted to 5.6 and in addition, ampicillin (1 $\mathrm{mg} / 100 \mathrm{ml}$ ) was added prior to sterilization to inhibit the growth of bacteria. The plates were incubated at room temperature for $48 \mathrm{~h}$ for bacteria and $72 \mathrm{~h}$ for fungi to obtain distinct colonies.

\section{Identification of bacterial isolates}

Pure cultures of bacteria isolates were presumptively identified on the basis of their morphological and biochemical characteristics. The results were compared with the scheme of Bergey's Manual of Determinative Bacteriology (Buchanan and Gibbons, 1974), further confirmation was by the use of Analytical Profile lndex (API 20E, BioMerieux, Inc, Durham, USA).

Hydrocarbon analysis using gas chromatography (GC)

Gas chromatography was carried out in order to determine the residual hydrocarbon content in the media during the incubation period. A Hewlett Packard (HP) 5890 series II (California, USA) with a flame ionization detector (FID) was used. Instrument operating conditions were as follows: an OV-3 glass column pack with internal diameter of $5.3 \mathrm{~m}$ and length of $30 \mathrm{~m}$ packed with porapak $\mathrm{N}, 60 / 100$, a column temperature of $200{ }^{\circ} \mathrm{C}$, an injector temperature of $60{ }^{\circ} \mathrm{C}$, a detector temperature of $280{ }^{\circ} \mathrm{C}, \mathrm{N}_{2}$ carrier gas and $\mathrm{H}_{2}$ at a flow rate of $22 \mathrm{ml} / \mathrm{min}$ and temperature/ramping rate of $5{ }^{\circ} \mathrm{C} / \mathrm{min}$. A standard profile was first obtained by injecting $1.0 \mathrm{ml}$ of the hydrocarbon into the GC and a chromatogram was generated to serve as a calibration window with which the test sample was analyzed. After generating the standard profile, $10.0 \mathrm{~g}$ of the test sample was extracted with $10 \mathrm{ml}$ acetone in a separation funnel, a 3-step serial extraction was carried out and was concentrated to $1.0 \mathrm{ml}$ from which $1 \mu \mathrm{l}$ was injected into the GC column and an equivalent chromatogram was generated. The peak areas of the standard and test sample chromatograms were compared to calculate the concentration of the sample. This is given by the formula:

Concentration of hydrocarbon $=$

Total peak of sample x Concentration of standard Peak area of standard

\section{RESULTS}

Identification of selected hydrocarbon utilizing bacterial

The hydrocarbon utilizers which were presumptively identified using conventional biochemical characteristics include: Pseudomonas, Burkbolderia, Bacillus, Corynebacterium, Aspergillus, and Penicillum species. The isolates selected for further experiments displayed better capability to utilize hydrocarbon in this study. Using the API kit, they were further identified as Bacillus thuringensis (strain LG 32) and Burkholderia pseudomallei (strain A81) as shown in table 1. 
Table 1: Cell morphology, biochemical characteristics and identification of selected bacterial isolates

\begin{tabular}{lll}
\hline Biochemical characteristics & LG32 & A81 \\
\hline Cellular morphology & Rods & Rods \\
Gram reaction & + & + \\
Catalase & + & - \\
Oxidase & + & + \\
Indole & - & - \\
Motility & + & + \\
Methyl red & - & - \\
Voges proskaeur & - & - \\
Citrate & + & + \\
Urease & - & - \\
Starch hydrolysis & + & - \\
Gelatin hydrolysis & + & + \\
Nitrate reduction & + & + \\
Spore test & + & - \\
Hydrolysis of blood & + & + \\
H2S production & - & - \\
Sugar fermentation & & \\
Glucose & + & - \\
Lactose & - & - \\
Sucrose & + & - \\
Arabinose & - & - \\
Fructose & + & - \\
Galactose & - & - \\
Xylose & - & - \\
Mannitol & - & + \\
Sorbitol & - & - \\
Manose & - & + \\
\hline Identity & Bacillus thuringensis & Burkolderia pseudomallei \\
\hline Keys - & &
\end{tabular}

Keys: - =negative, $+=$ positive

Effect of bacterial and fungal population on potassium and phosphorus content and subsequent effect on the residual oil concentration of soil samples

The increase in total microbial population (Fig. 1A) led to a marked reduction in the available phosphorus from $70 \mathrm{mg} / \mathrm{kg}$ (day 0) to $10 \mathrm{mg} / \mathrm{kg}$ by day 28 in the bioaugmented and biostimulated soil compared with that of the control $(30 \mathrm{mg} / \mathrm{kg}$ at day 0 to $10 \mathrm{mg} / \mathrm{kg}$ by day 28). The same trend was observed with the potassium content, there was a significant reduction in the potassium content from $0.3 \mathrm{mg} / \mathrm{kg}$ (day 0) to $0.02 \mathrm{mg} / \mathrm{kg}$ by day 28 in the bioaugmented and biostimulated soil compared with that of the control $(0.03 \mathrm{mg} / \mathrm{kg}$ to $0.01 \mathrm{mg} / \mathrm{kg}$ ) (Fig.1B). The result showed that addition of nutrients (phosphorus and potassium) stimulated the growth of both HUB and HUF and hence there was a marked reduction in the residual oil concentration in the bioaugmented and biostimulated soil microcosm from $(1.35 \mathrm{~g} / \mathrm{kg}$ (day 0) to $0.2 \mathrm{~g} / \mathrm{kg}$ (day 28) compared with that of the control $1.35 \mathrm{~g} / \mathrm{kg}$ at day 0 to $1.0 \mathrm{~g} / \mathrm{kg}$ by day 28) (Fig.1G). There was an increase in the mean values for total viable counts (TVC) of the population of hydrocarbon utilizing fungi (HUF) in the bioaugmented soil and in the bioaugmented soil enhanced with stimulation. However, in the bioaugmented soil, the mean values for total viable counts of population of HUB ranging from 5.5$7.5 \log 10 \mathrm{cfug}^{-1}$ were more than the HUF which ranged from 3.0-5.5log10 $\mathrm{cfug}^{-1}$. Conversely, the $\log$ (TVC) increase in the population of hydrocarbon utilizers in the bioaugmented soil enhanced with stimulation were 6.0-9.0 $\log 10 \mathrm{cfug}$ for bacteria and 3.0-6.5 $\log 10 \mathrm{cfug}^{-1}$ for fungi compared with the control (HUB: 4.6-6.0 and HUF: 2.8-3.0log10 $\mathrm{cfug}^{-1}$ ) (Fig. 1E and F). Also, total heterotrophic counts ranged from 5.09.0log10 cfug $^{-1}$ ) for bacteria and 3.5-4.75 $\log 10 \mathrm{cfug}^{-}$ $\left.{ }^{1}\right)$ for fungi (Fig. 1C and D). 

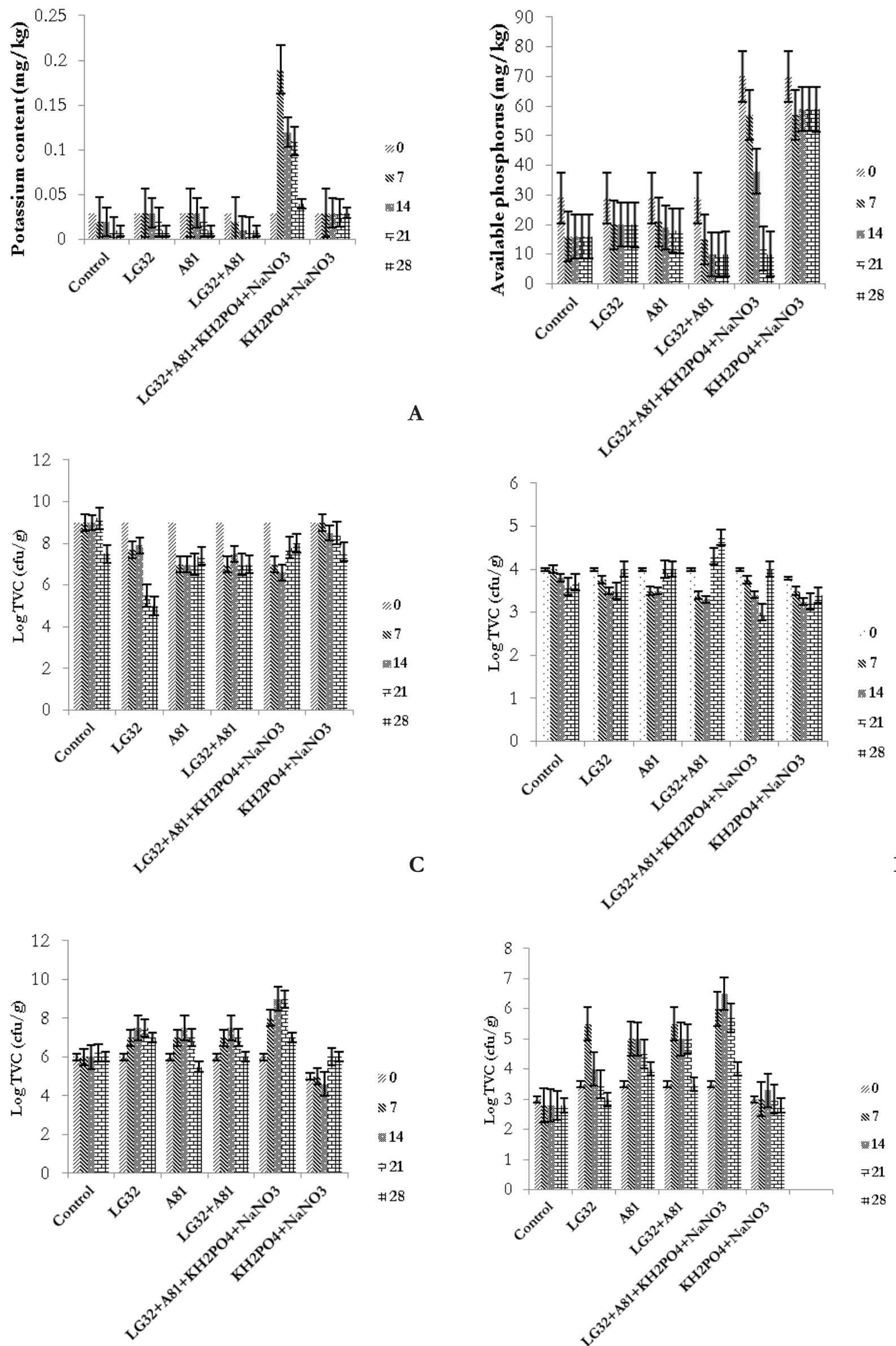


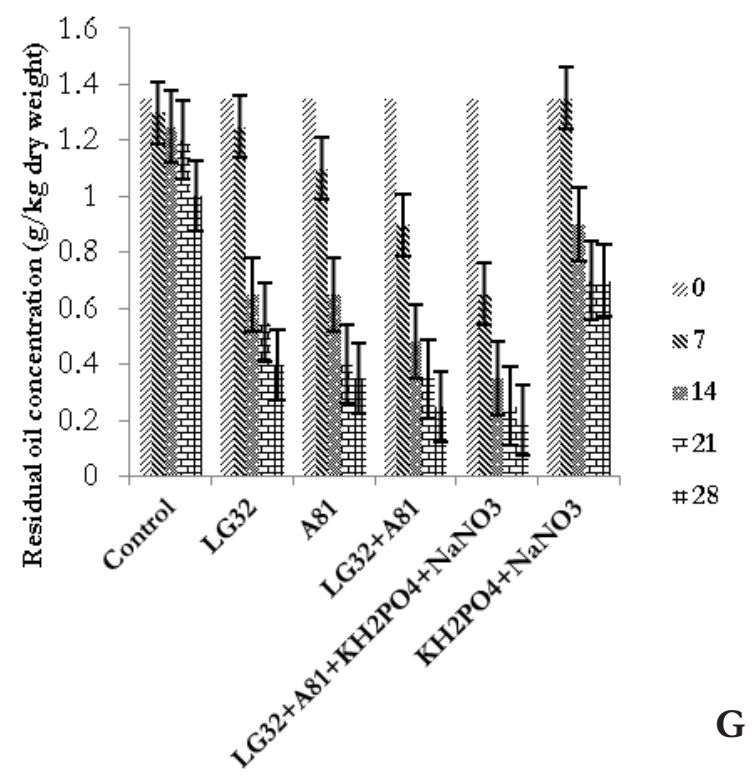

Figure 1: Changes in the: Potassium content (A); Available phosphorus (B); Total heterotrophic bacterial counts $(\mathrm{C})$; Total heterotrophic fungal counts (D); Total hydrocarbon Utilizing bacteria counts(E); Total hydrocarbon Utilizing fungi counts (F); Residual oil concentration (G). LG32-Bacillusthuringensis A81-Burkolderia pseudomallei

\section{Gas chromatographic profiles}

The GC result indicated that by day 35 , most of the hydrocarbon contents were removed (96.92 $\%)$, evident by the drastic reduction in the peak heights of the aliphatic and aromatic components in the augmented soils compared with the control. The GC profiles for the reduction in the hydrocarbon contents of soil samples are shown in figures $2 \mathrm{~A}-\mathrm{E}$.

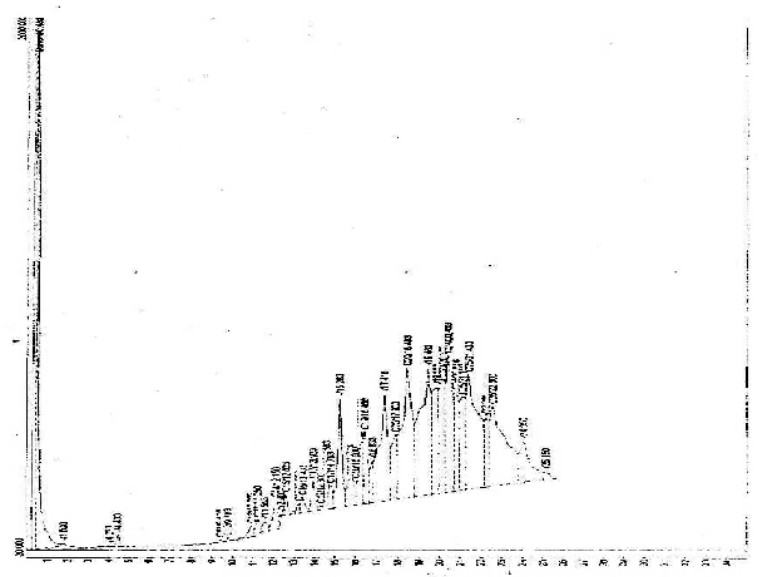

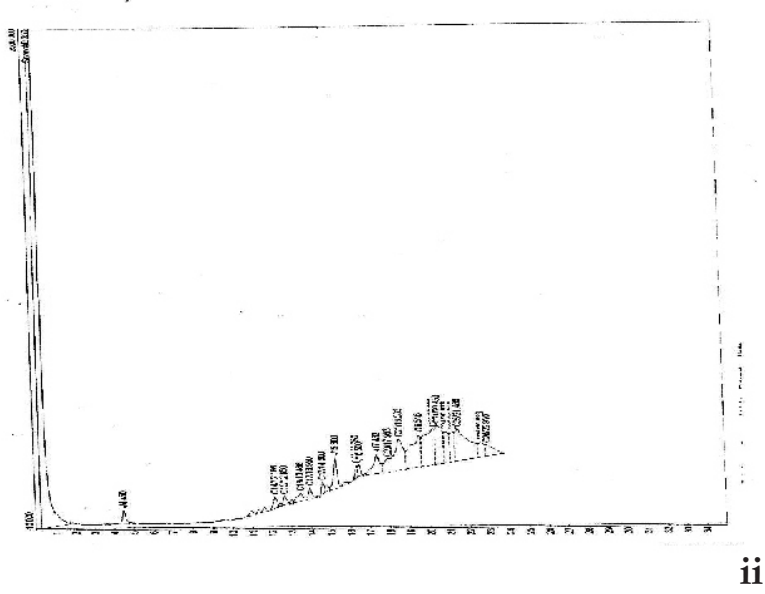

Fig.2A (i and ii): Gas chromatography profiles for soil polluted with crude oil under natural attenuation (Control) i.e. Polluted soil without addition of isolates or nutrients at day 0 , and after 35-days respectively. Note the slight reduction in the pick heights, indicating that the pollutant has reduced slightly
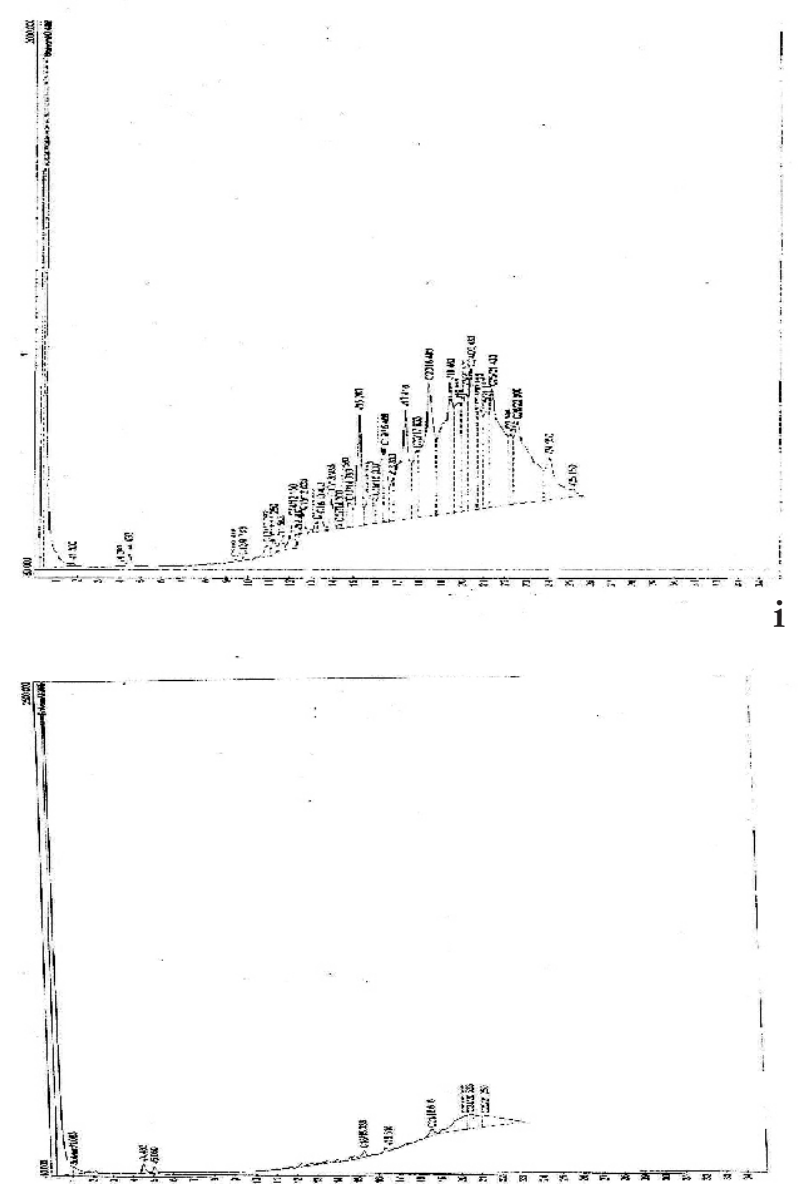

ii

Fig.2B (i and ii): Gas chromatography profiles for soil polluted with crude oil without augmentation (i) and augmented with strain LG32 (ii), after 35-days. Note the observable marked reduction in pick heights suggesting that the organism is most likely to be utilizing the crude oil for growth. 

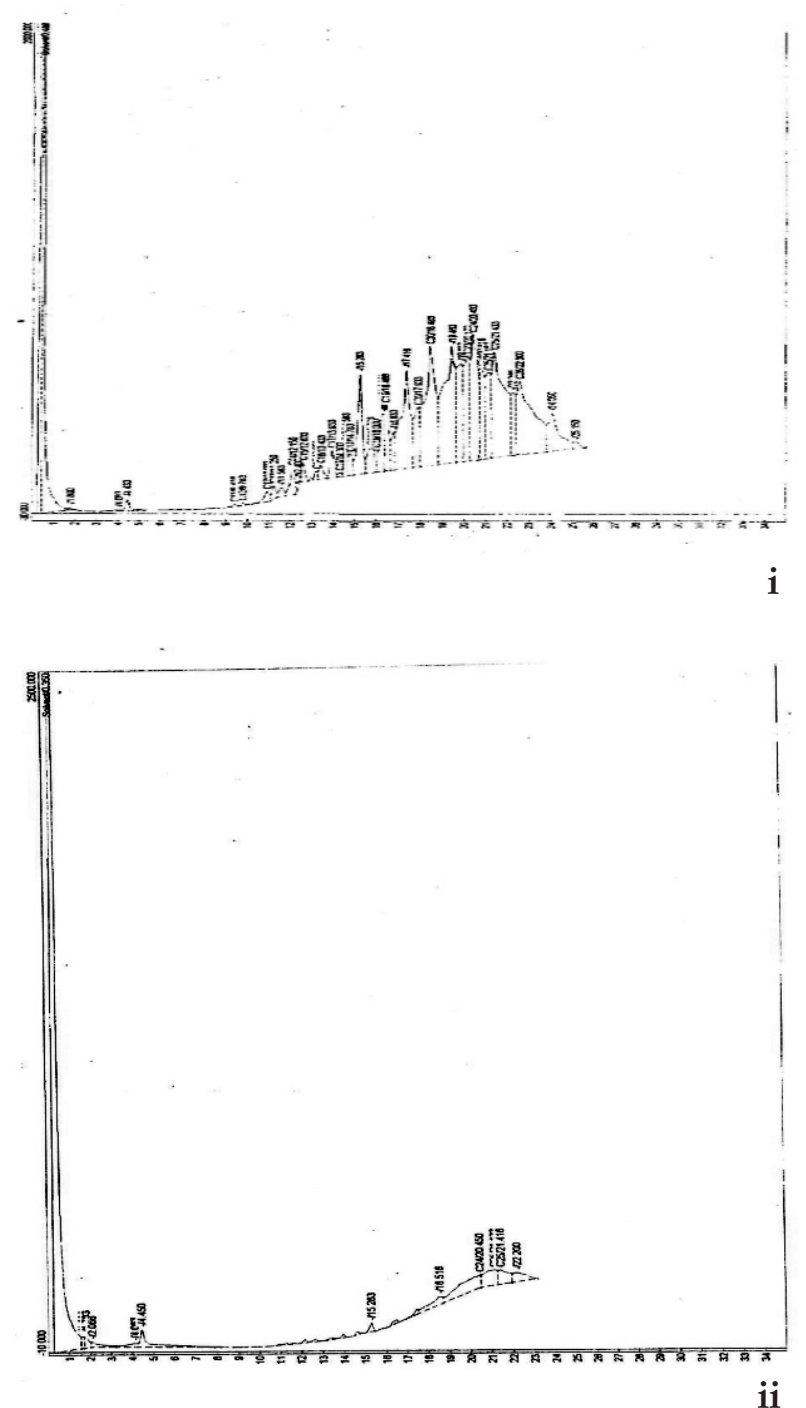

Fig.2C (i and ii): Gas chromatography profiles for soil polluted with crude oil without augmentation (i), and augmented with strain (A81) after 35-days. There was marked removal of the crude oil.

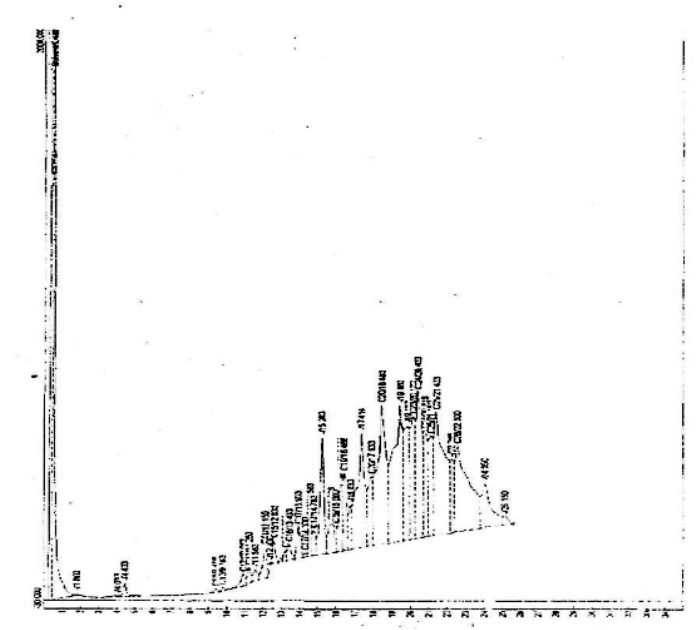

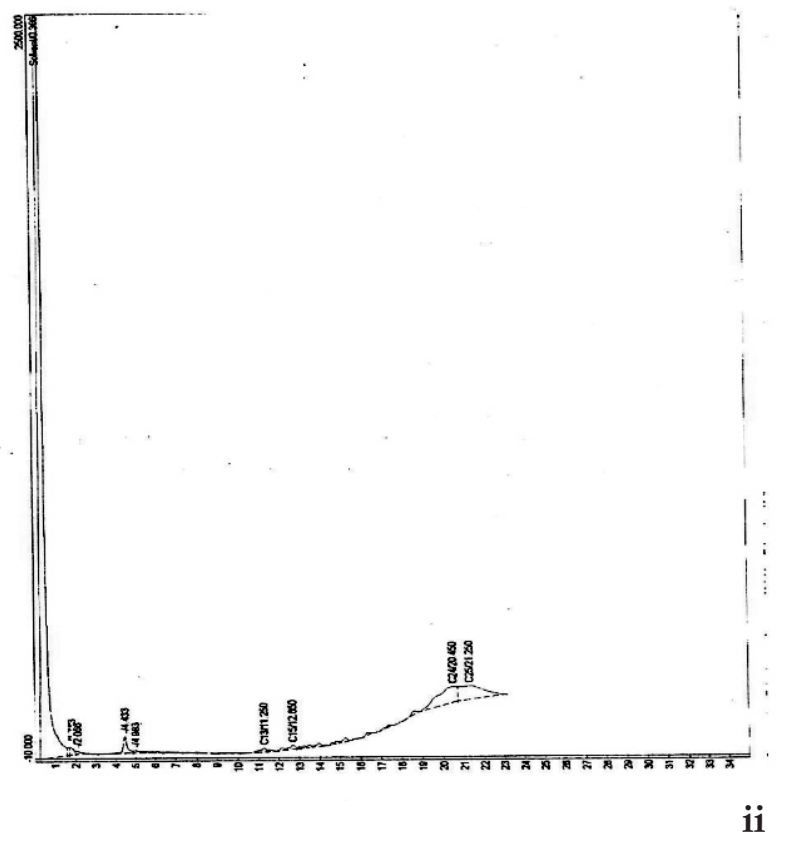

Fig.2D (i and ii): Gas chromatography profiles for soil polluted with crude oil without augmentation (i) and with augmentation (ii) after 35-day period. A combination of the two isolates was used for the augmentation. Note the highly significant action in the pick height. 


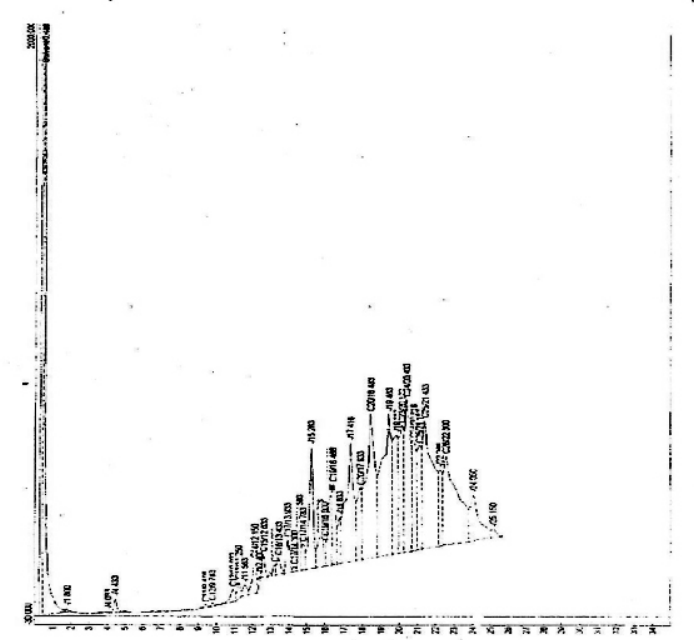

ii

Fig.2E (i and ii): Gas chromatography profiles for soil polluted with crude oil without (i) and with (ii) biostimulation, after 35-day incubation period. Nutrients $\left(\mathrm{KH}_{2} \mathrm{PO}_{4}+\mathrm{NaNO}_{3}\right)$ were used for biostimulation. Note the rapid removal of pollutants, indicating that sufficient nutrients in soil could increase the rate and amount of crude oil (pollutant) removal by indigenous microorganisms

\section{DISCUSSION}

Bacteria that are capable of degrading hydrocarbon appear to be widely distributed in polluted and non-polluted soil habitats because microorganisms capable of utilizing hydrocarbons are widespread in nature and may not be restricted to hydrocarbon bearing environments (Atlas, 1995; Amund, 2000; Ijah and Antai, 2003).The hydrocarbon utilizers isolated in this study include Pseudomonas, Bacillus, Burkolderia, Corynebacterium, Aspergillus and Penicillium species, and are similar to the ones obtained by Ijah and Antai (2003). These organisms have been recognized as having the capability of degrading hydrocarbon polluted environments (Devereux and Sizemore, 1982). The higher counts of bacteria compared with those of fungi may be as a result of nutrient status and other environmental factors of the soil (Jobson et al., 1974). Bacteria are known to be better adapted to extreme environmental factors most especially $\mathrm{pH}$, temperature and oxygen compared to their fungal counterpart. It may also be due to the presence of some toxic component which does not favour fungal growth; it is well known that some bacteria are capable of producing varieties of antimicrobials which enables them to be better competitors within the soil environment (Colwell and Walker, 1977). The increase in the population of hydrocarbon utilizing bacteria and fungi leading to a marked reduction in the available phosphorous and potassium in the bioaugumented and biostimulated soil compared with that of the control in this study showed that the addition of nutrients stimulated the growth of both HUB and HUF; hence there was a marked reduction in the residual oil concentration in the bioaugmented and biostimulated soil microcosm from $1.35 \mathrm{~g} / \mathrm{kg}$ (day 0) to $0.2 \mathrm{~g} / \mathrm{kg}$ (day 28) compared with that of the control $(1.35 \mathrm{~g} / \mathrm{kg}$ at day 0 to $1.0 \mathrm{~g} / \mathrm{kg}$ at day 28). With the addition of key nutrients (biostimulation), the natural indigenous microorganisms in the soil sample showed obvious higher rate of hydrocarbon removal, a suggestion that nutrient is a major factor in natural attenuation of hydrocarbon contaminants.

This study also confirmed the reductions in peak areas of the aliphatic and aromatic components in the various soil samples. It was observed that by day $35,96.92 \%$ of the aliphatic and aromatic components have been degraded in the augmented soil while for the control $65.61 \%$ degradation of the total hydrocarbons in the crude oil occurred. Chikere and Okpokwasili (2001) have previously found that natural biodegradation process removes considerable quantities of oil from the soil environment with indigenous bacteria playing the dominant role.

A number of properties that may affect the functionality and quality of the soil, and consequently influence the rate of degradation of hydrocarbons in soil include $\mathrm{pH}$, salt content, presence of nutrients, oxygen content, particle size and distribution, buffer capacity and temperature. The $\mathrm{pH}$ values of crude oil polluted soil without augmentation (control) were lower (6.31 -7.2) compared to those of the crude oil polluted soil microcosm with augmentation (6.98.1). This is an indication that biodegradation may be adversely affected by low $\mathrm{pH}$. According to Subhas and Irvine (1998), soil $\mathrm{pH}$ values are related to the size of the organisms present and the multiplicity of enzymes at the microbial level. Bacteria tend to have optimum $\mathrm{pH}$ between 6.5 
and 7.5 which equal the intracellular $\mathrm{pH}$. Moreover, biodegradation of a compound is dependent on specific enzymes which are secreted by the organisms and these enzymes are largely $\mathrm{pH}$ dependent.

\section{CONCLUSION}

Microbial removal of crude oil from polluted soil microcosms was observed to have occurred in all the soil samples studied. However, the quantity of crude oil removed was higher in the bioaugmented and biostimulated samples compared to that of natural attenuation (control), Therefore, bioaugmentation and biostimulation are suggested as efficient methods to attenuate or cleanup crude oil and hydrocarbon - polluted environments. Further work will focus on the assay and detection of the requisite enzymes in the genome of the selected bacterial strains used in this study.

\section{REFERENCES}

Aboribo, R. I. 2001. Oil politics and Niger Delta Development commission. The tussle for control and domination. Afr. J. Environ Studies. 2,168-175.

Adedokun, O.M. and Ataga, A.E. 2007. Effects of amendments and bioaugmentation of soil polluted with crude oil, automotive gasoline oil and spent engine oil on the growth of cowpea (Vigna ungiculata L. Walp). Sci. Res. Essays 2(5), 147-149

Akubugwo, E. I., Ogbuyi, G. C., Chinyere, C. G. and Ugbogu, E. A. 2009. Physicochemical properties and Enzymes activity studies in a refined oil contaminated soil in Isiukwuato, Abia State, Nigeria. Biokemistri 21(2), 79-84.

Amadi, E. N., Okol, J. C. and Odu, C. T. I. 2005. Optimising Crude oil degradation in a sandy soil: Effects of urea-nitrogen and phosphoric acid. Phosphorus. J. Niger. Environ. Soc. 2(3), 322-329.

Amouric, A., Verhe, F. Auria, R. and Casalot, L. 2006. Study of hexane-degrading consortium in a biofilter and in liquid culture: biodiversity, kinetics and characterization of degrading strains. FEMS Microbiol. Ecol. 55(2), 239-247.

Amund, O. O. 2000. The oil Eating Microbe: A Remedy to the menace of oil pollution.
(An Inaugural Lecture Delivered at the University of Lagos on Wednesday, the $19^{\text {th }}$ of January 2000). University of Lagos Press, Pp.11-26.

Anon 2003. Remediation of PetroleumContaminated Media [online]. Bioremediation: An Alternative Tool Available at URL http.//www. xlenvironmental.com/library/winter.htm $>$ (Accessed 15 June 2006)

Atlas, R. M. 1977. Stimulated petroleum Biodegradation. Critical Rev. Microbial. 5,371-386.

Atlas, R. M. 1981. Microbial degradation of petroleum of Hydrocarbon: An Environmental Perspective Microbiology. Rev. 45,180-209.

Atlas, R. M. 1992. Petroleum microbiology. In: Encyclopedia of Microbiology. Lederberg, J. (ed). Academic Press, Baltimore, pp.363-369.

Atlas, R. M. 1995. Petroleum Biodegradation and oil spill Bioremediation. Mar. Pollut.Bull. 31,178-182

Buchanam, R.E. and Gibbons, N.E. 1974. Bergey's Manual of Determinative Bacteria, The Williams and Wilkins Company, Baltimore, 246 pp.

Chandra, M. S. and Norhusna, M.N. 2012. Relationship between SARA fractions and crude oil fouling. J. Appl. Sci. 12, 24792483.

Chikere, B. O., and Okpokwasili, G. C. 2001. Organic pollution in Niger Delta River Receiving Petrochemical Effluents. Trop. Freshwater Bio. 10, 19-33.

Cho, V. and Na, J-G., Nlo, N-S., Kim, S. and Kim, S. 2012. Application of saturated, Aromatics, Resins and Asphaltenes crude oil fractionation for detailed chemical characterization of Heavy crude oils by Fourier Transform ion cyclotron Resonance mass spectrometry Equipped with Atmospheric pressure photoionization. Energy Fuels 26(5), 2558-2565.

Colwell, R. R. and Walker, J. D 1977. Ecological Aspects of Microbial Degradation of Petroleum in the Marine Environ. Crit. Rev. Microbial. 5, 423-445

Cunningham, C. J. and Philip, J. C. 2000. 
Comparison of Bioaugmentation and Biostimulation in Ex-situ Treatment of Diesel contaminated soil. Land contam. Reclam. 8, 261-269.

Davis, D. L., Bradlow, H. L, Wolfe, M, Woodruff, T., Hoel, D. G.and Anton Culver, H. 1993. Medical Hypothesis: Xenostrogens as preventable causes of Breast cancer. Environ Health Persepect. 101, 372-377.

Devereux, R and Sizemore, R. K. 1982. Plasmid incidence in marine Bacteria Isolated from petroleum polluted sites on different petroleum Hydrocarbons. Mar. Pollut. Bull. 13,198-202.

Irwin, R. J. 1997. Benzo(a) pyrene entry, Environmental contaminants Encyclopedia, National Park Service with assistance from Colorado state Univ., Student Assistant contaminants specialist. 1201 Oakridge Drive, Suite 250 Fort Collins, Colorado 80525.

Jobson, A. M., Mclaughlin, F. D., Westlake, D. W. 1974. Effects of Amendments on Microbial uitilization of oil Applied to soil. J. Applied Micro Biol.27,166-170.

Jones, D. M., Head, I. M., Gray, N. D., Adams, J. J., Rowan, A. K., Aitken, C. M., Bennett, B., Huang, H., Brown, A.,Bowler, B. F. J., Oldenburg, T., Erdman, M. and Larter, S. R. 2007. Crude oil biodegradation via methanogenesis in subsurface petroleum reservoirs. Nature doi: 10.1038/nature 06484.

Kobayashi, H. and Rittman, B. E. 1982. Microbial Removal of Hazardous Organic Compounds. Environ Sci. Technol. 19 (3), 470-481.

Kastner, M., BremerJammali, M. and Mahro, B. 1994. Enumeration and characterization of the soil Microflora from hydrocarbon contaminated soil sites able to Mineralize Polycyclic Aromatic Hydrocarbons. Appl. Microbiological Biotechnol. 41, 267-273.

Ko, S. H. and Lebeault, J. M. 1999. Effect of a mixed culture on co-oxidation during the degradation of saturated hydrocarbon mixture. J. Appl. Microbiol. 87, 72-79.

Koukkou, A. I. and Vandera, E. 2011. Hydrocarbon-degrading soil Bacteria: Current Research. Caister Academic Press Norfolk, U.K 271pp.
Leahy, J. G. and Cowel, R. R. 1990. Microbial Degradation of Hydrocarbons in the Environment. Microbiol. Rev. 54, 305-315

Ijah, J. and Antai, 2003. Degradation and Mineralization of crude oil by Bacterial. Lett. Appl. Microbiol. 12, 72-76.

Mohamed, M., Ramadan, A., Knudsen, T.S, Antić, M., Beškoski, P. B., Vrvić, M. M., Schwarzbauer, J. and Branimir Jovančićević, B. 2013. Degradability of nalkanes during ex situ natural bioremediation of soil contaminated by heavy residual fuel oil (mazut). J. Serb. Chem. Soc. 78 (7), 1035-1043.

Nano, G., Borror, I, A. and Rita, R. 2003. Combined Slurry and Solid-Phase Bioremediation of Diesel Contaminated Soils. J. Hazardous Materials. 100, 79 - 94.

Obayori, O. S., Ilori, M. O., Adebusoye, S. A., Oyetibo, G. O., Omotayo, A. E. and Amund, O. O. 2009. Degradation of hydrocarbons and biosurfactant production by Psendomonas sp. strain LP1. WorldJ. Microbiol. Biotechnol.25, 1615-1623

Odjegba, V. J. and Sadiq, A. O. 2002. Effect of spent chlorophyll on the Growth Parameters, chlorophyll and protein Levels of Amaratus hybrids L. The Environmentalist 22, 23-28.

Ogboghodo, I. A., Azenabor, U. F. and Osemwota, I. O. 2005. Amelioration of Crude oil polluted soil with poultry manure and the effect on growth of maize and some soil properties. J. Plant Nutr. 28(1), 21-32

Ojo, M. O. and Adebusuyi. 1996. The state of Nigerian Petroleum Industry: performance, problems and outstanding issues, $\mathrm{CBN}$ Economic and Financial Review 34.

Onifade, A .K., Abubakar, F. A. and Ekundayo, F. O. 2007. Bioremediation of crude oil polluted soil in the Niger Delta Area of Nigeria using Enhanced natural Attenuation. Res.J. Appl. Sci.2(4), 498-504.

Onuh, M. O., Madukwe, D. K. and Ohia, G. U. 2008a. Effects of poultry manure and cow dung on the physical and chemical properties of crude oil polluted soil. Sci. World J. 3(2), 45-50.

Onuh, M. O., Ohazurike, N. C. and Maduekwe, D. K. 2008b. Interaction of crude oil and 
manure treatments and its effects on the agronomic characteristics of maize (Zea mays L.). Sci. World J.3(2): 107-111.

Onuocha, C. I., Arinze, A. E. and Ataga, A. E. 2003. Evaluation of growth of some fungi in crude oil polluted Environment. Glob.J. Agric. Sci. ISSN 2, 1596-2903.

Raymond, R. L., Hudson, J.O. and Jamison, V.W. 1976. Oil Degradation in Soil. Appl. Environ. Microbiol.31, 5220-535.

Rushton, D. G., Ghaly, A.E. and Martinell, K. 2007. Assessment of Canadian regulations and remediation methods for diesel oil contaminated soils. American J.
Appl. Sci. 4 (7), 465-478.

Speight, J. 2014. Handbook of petroleum products Analysis $2^{\text {nd }}$ edition John Wiley and Sons Publisher, NJ, USA 368pp.

Subhas, K. S. and Irvine, R. L. 1998. Bioremediation fundamentals and Applications. Technomic publishing, 1,283-290.

Ukoli, M. K. 2003. Environmental factor in the management of the oil and gas industries in Nigeria. Nigerian National Petroleum Corporation (NNPC) p2. 